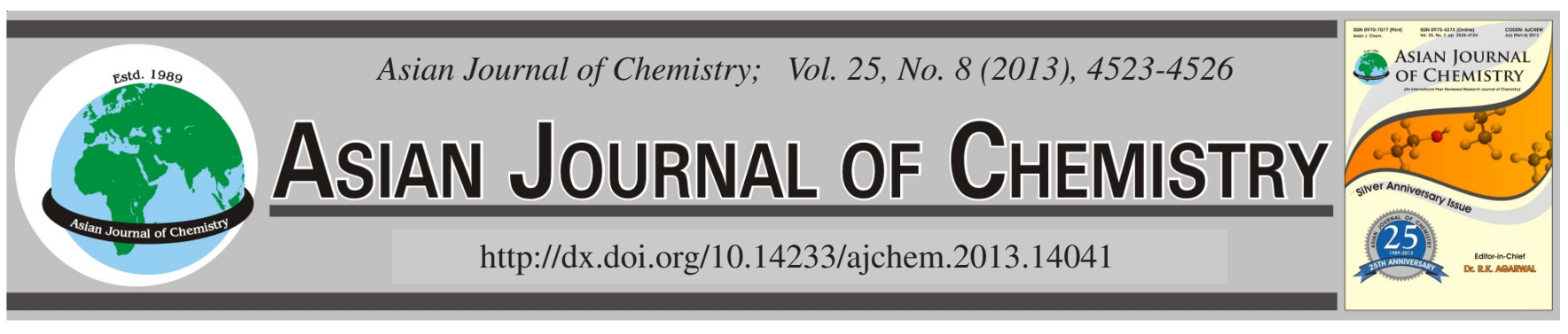

\title{
Preparation and Catalytic Performance of Ionic Liquid Catalyst Immobilized by $\mathrm{ZrO}_{2}$
}

\author{
JiAnwei Lian ${ }^{1}$, JiAnLing XIA $^{1,2, *}, \mathrm{Kun} \mathrm{HuANG}^{1}$ and Mei $\mathrm{Li}^{1}$
}

${ }^{1}$ Institute of Chemical Industry of Forestry Products, CAF; Key Laboratory of Biomass Energy and Material, Jiangsu Province; National Engineering Laboratory for Biomass Chemical Utilization; Key and Lab. on Forest Chemical Engineering, SFA, Nanjing 210042, P.R. China ${ }^{2}$ Institute of Forest New Technology, CAF, Beijing 100091, P.R. China

*Corresponding author: E-mail: lianjw868@163.com; xiajianling@126.com

\begin{abstract}
A novel Brønsted acidic ionic liquid catalyst $\left[\mathrm{HSO}_{3}-\mathrm{bmim}\right]^{+}\left[\mathrm{HSO}_{4}\right]^{-}$loaded by $\mathrm{ZrO}_{2}$ was prepared under impregnation method and characterized by means of X-ray diffraction, FT-IR spectroscopy, thermogravimetric analysis-derivative thermogravimetry, scanning electron microscope and element analysis. The results showed that the capacity of ionic liquid $\left[\mathrm{HSO}_{3}-\mathrm{bmim}^{+}\left[\mathrm{HSO}_{4}\right]^{-}\right.$was $21.01 \%$. The catalyst can be used in the esterification of maleic anhydride and iso-octanol and the convertion rate of maleic anhydride was $99.8 \%$ under the following conditions: $140{ }^{\circ} \mathrm{C}$, maleic anhydride $0.05 \mathrm{~mol}$, iso-octanol $0.2 \mathrm{~mol}$, toluol $6 \mathrm{~g}$, catalyst $0.8 \mathrm{~g}$ and reaction time 100 min. The esterification could still reach to $94.9 \%$ after the catalyst was reused for 9 times. The catalyst has exhibited good thermal stability and repeatability performance.
\end{abstract}

Key Words: $\mathrm{ZrO}_{2}$, Ionic liquid, Supported catalyst, Esterification.

\section{INTRODUCTION}

Ionic liquid, which is acidic adjustable and have good stability and solubility in chemical reactions is a new-type efficient environmental-friendly catalyst ${ }^{1,2}$. However, this kind of catalytic reactions belongs to homogeneous catalysis. Products and reactants can't separate instantly though most of ionic liquid can subside after the reaction (when the reaction system to room temperature). Therefore, the catalyst can't be industrialized, which enormously limits its industrial application.

Loaded ionic liquid can immobilize ionic liquid, in response to the separation of the catalytic after the reaction, which speed up the industrial application of ionic liquid and make the research of its properties a hot spot ${ }^{3-5}$. However, the researches at present are mainly focus on loading ionic liquids on $\mathrm{SiO}_{2}{ }^{6,7}$, molecular sieve ${ }^{8}$ and nanoparticles ${ }^{9-11}$ through chemical bonding and grafting. Zhang et al. ${ }^{12}$ used $\mathrm{SiO}_{2}$ as the carrier to load ionic liquid [(TESP) MIM] $\mathrm{HSO}_{4}$. When use this catalyst in the esterification reaction of acetic acid and butanol, the esterification rate of $99.4 \%$ and after reused for 6 times the esterification rate still can up to $74.7 \%$. Shen et al. ${ }^{13}$ prepared ionic liquid-Pro/SBA-15 catalyst with ionic liquid and SBA-15 mesoporous molecular sieves, which showed excellent catalytic performance in Knoevenagel condensation reaction. However, the preparation is complicated and the cost is high, so that it can't play the significant role to the industrialization of ionic liquid.

In this paper, an ionic liquid loaded catalyst is prepared, in which $\mathrm{ZrO}_{2}$ is used as a supporter to load ionic liquid $\left[\mathrm{HSO}_{3}-\right.$ bmim $]^{+}\left[\mathrm{HSO}_{4}\right]^{-}$under impregnation method. The preparation is simple and the catalysis in esterification reactions is good. Meanwhile, the catalyst has some other advantages, such as the long service life and hard to be poisoned, which has important meaning in the industrialization of the use of ionic liquid.

\section{EXPERIMENTAL}

Maleic anhydride (A.P.), isooctanol (A.P.), toluene (A.P.), cyclohexane (A.P.), zirconium oxychloride (A.P.), hexadecy ltrimethyl ammonium bromide (CTAMBr, A.P.), ammonia (A.P.), concentrated $\mathrm{H}_{2} \mathrm{SO}_{4}$ (A.P.), 1,4-sulfonylurea lactone, 1-methyl imidazole.

$\mathrm{D}_{8}$ FOCUS XRD (BRUKER, Germany), S-3400 scanning electron microscopy (Toshiba, Japan), STA 409 thermogravimetric analyzer, (Netzsch, Germany), Magna-IR550 FT-IR (Nicolet, USA), Elementar Vario ELIII Element analyzer; BS110S electronic balance (Bejing Saiduoli Inc., China), SHZC vacuum pump(Yingyu electronic instrument factory, China), temperature control system, JJ-1 electric mixer (Guohua Inc., China), HH-4 digital electronic constant temperature waterbath (Aorui equipment factory, China). 


\section{Preparation of catalyst}

$\left[\mathrm{HSO}_{3} \text {-bmim }\right]^{+}\left[\mathrm{HSO}_{4}\right]^{-}$: Ionic liquid $\left[\mathrm{HSO}_{3} \text {-bmim }\right]^{+}$ $\left[\mathrm{HSO}_{4}\right]^{-}$is prepared through the method refers to literature ${ }^{14}$. Dissolve 1 mol of 1,4-butane sulfonylurea lactone into toluene and dropwise add 1 mol 1-methyl imidazole under magnetic stirring. Then heat it up to $80^{\circ} \mathrm{C}$ for $2 \mathrm{~h}$, after which the reaction liquid is filtered. Wash the white precipitate with ethyl acetate three times and vacuum dry $5 \mathrm{~h}$ at $100^{\circ} \mathrm{C}$, then the intermediate 1-methyl imidazole inside sulfonate is got. Dissolve the intermediate into deionized water, dropwise add $1 \mathrm{~mol} 98 \% \mathrm{H}_{2} \mathrm{SO}_{4}$ under room temperature, then heat it up to $90^{\circ} \mathrm{C}$ for $2 \mathrm{~h}$, dehydrate in vacuum and $\left[\mathrm{HSO}_{3} \text {-bmim }\right]^{+}\left[\mathrm{HSO}_{4}\right]^{-}$ionic liquid which is light yellow viscous liquid is obtained.

Preparation of $\mathrm{ZrO}_{2}{ }^{15}$ : Add $2.0 \mathrm{~g}$ CTAMBr into $24 \mathrm{~mL}$ deionized water, stir well to get mixture A. Soluble $25.8 \mathrm{~g}$ oxygen chlorinated zirconium in $24 \mathrm{~mL}$ deionized water to get mixture B. Dropwise add B into A under intense stiring and adjust $\mathrm{pH}$ to 8-9 with ammonia, then keep stiring for $1 \mathrm{~h}$ and static cool down till the foam disappears. Pour the mixture into the reaction kettle with PTFE, take crystallization for 24 $\mathrm{h}$ under $105^{\circ} \mathrm{C}$, then get the white powder. After wash it with absolute ethyl alcohol to neutral, roast $3 \mathrm{~h}$ in the muffle furnace under $500{ }^{\circ} \mathrm{C}$ and $\mathrm{ZrO}_{2}$ is obtained.

$\left[\mathbf{H S O}_{3} \text {-bmim }\right]^{+}\left[\mathbf{H S O}_{4}\right]^{-/} / \mathbf{Z r O}_{2}{ }^{{ }^{16}}$ : Dropwise add $\left[\mathrm{HSO}_{3^{-}}\right.$ bmim $]^{+}\left[\mathrm{HSO}_{4}\right]^{-}\left(4.5 \mathrm{~g}\right.$ ) on the roasting $\mathrm{ZrO}_{2}(5.0 \mathrm{~g})$, then add $2 \mathrm{~mL}$ anhydrous alcohol. After stirring to uniformity with the magnetic stirring apparatus, ultrasonic clean it for $2 \mathrm{~h}$, then seal and stir under room temperature for $24 \mathrm{~h}$. Excessive ionic liquid is extracted by dichloromethane in the Soxhlet extractor $\left(40{ }^{\circ} \mathrm{C}, 24 \mathrm{~h}\right)$. At last, vacuum dry $12 \mathrm{~h}$ under $110^{\circ} \mathrm{C}$ and $\left[\mathrm{HSO}_{3} \text {-bmim }\right]^{+}\left[\mathrm{HSO}_{4}\right]^{-} / \mathrm{ZrO}_{2}$ is obtained.

Esterification: Connect the $250 \mathrm{~mL}$ round bottom flasks with thermometer, water segregator and condenser, add 0.05 mol maleic anhydride, $0.2 \mathrm{~mol}$ isooctanol, catalyst and toluene, then start the backflow reaction under magnetic mixing. Take samples timely to determine the conversion rate. After the complete of the reaction, pour out the upper reaction liquid and the catalyst left can be used to evaluate the reutilization property.

Determination of conversion rate: According to GB1668-2008, sampling analysis the acid value of reaction system, then determine the conversion (y) of maleic anhydride in the esterification reaction on the basis of the change of acid value. Formula (1).

$$
\mathrm{y}=\left[1-\left(\mathrm{w}_{2} / \mathrm{w}_{1}\right)\right] \times 100 \%
$$

In the formula: $\mathrm{w}_{1}$-the system acid value before reaction; $\mathrm{w}_{2}$-the system acid value after reaction.

\section{RESULTS AND DISCUSSION}

Architectural feature of $\mathrm{ZrO}_{2}$ and $\left[\mathrm{HSO}_{3}-\mathrm{bmim}\right]^{+}$ [ $\left.\mathrm{HSO}_{4}\right]-/ \mathrm{ZrO}_{2}$ : In Fig. $1, \mathrm{~A}$ and $\mathrm{B}$ are wide angle XRD of $\mathrm{ZrO}_{2}$ and $\left[\mathrm{HSO}_{3}-\text { bmim }\right]^{+}\left[\mathrm{HSO}_{4}\right]^{-} / \mathrm{ZrO}_{2}$. The lattice plane value showed in $\mathrm{A}$ is the eigenvalue of tetragonal system, while the lattice plane value showed in B is the eigenvalue of monoclinic system. The figure indicates that a mixed crystal carrier $\mathrm{ZrO}_{2}$ is obtained after being roasted and the tetragonal phase has not only high crystallinity, but high content through the calculation and analysis of the diffraction intensity. The contrast of A and B shows that the peak form does not change significantly, which indicates ionic liquid doesn't obviously influence the crystal of $\mathrm{ZrO}_{2}$.
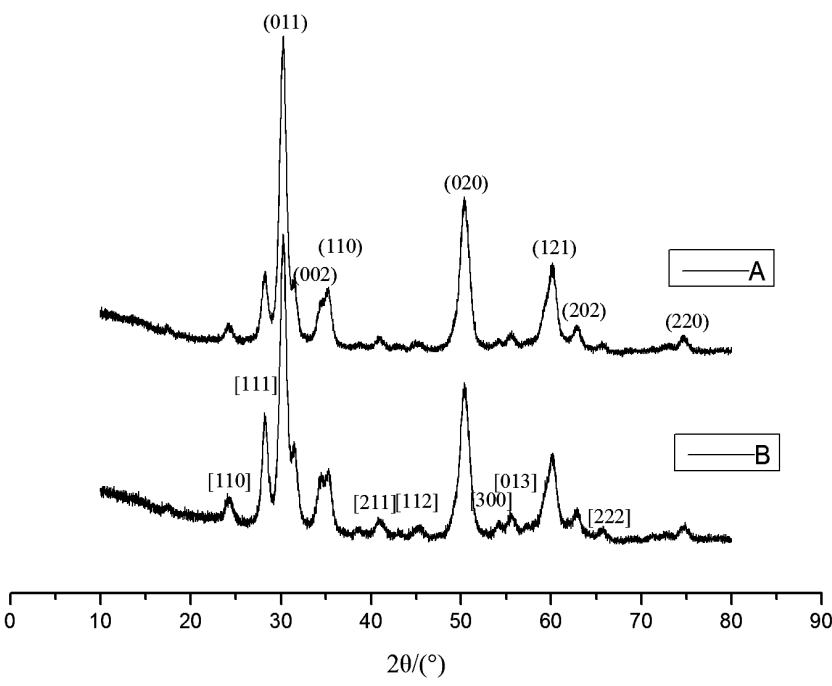

Fig. 1. XRD patterns of $\mathrm{ZrO}_{2}(\mathrm{~A})$ and $\left[\mathrm{HSO}_{3} \text {-bmim }\right]^{+}\left[\mathrm{HSO}_{4}\right]^{-} / \mathrm{ZrO}_{2}(\mathrm{~B})$

In Fig. 2, curves A, B and C are FT-IR spectrograms of $\mathrm{ZrO}_{2},\left[\mathrm{HSO}_{3} \text {-bmim }\right]^{+}\left[\mathrm{HSO}_{4}\right]^{-} / \mathrm{ZrO}_{2}$ and ionic liquid. In spectrograms $\mathrm{B}$ and $\mathrm{C}$, absorption peaks at $3156 \mathrm{~cm}^{-1}$ and $3115 \mathrm{~cm}^{-1}$ represent stretching vibration of aromatic $\mathrm{C}-\mathrm{H}$ on imidazole ring; absorption peak at $2953 \mathrm{~cm}^{-1}$ represents stretching vibration of methyl $\mathrm{C}-\mathrm{H}$ on imidazole ring; absorption peaks at 1709,1572 and $1461 \mathrm{~cm}^{-1}$ represent coupled vibration of $\mathrm{C}=\mathrm{C}$ in imidazole ring; $1233,1167,1031$ and $876 \mathrm{~cm}^{-1}$ represent characteristic absorption peak of $\left[\mathrm{HSO}_{4}\right]^{-}$. The contrast of $\mathrm{B}$ and $\mathrm{C}$ shows that absorption peaks at $1233 \mathrm{~cm}^{-1}$ and 876 $\mathrm{cm}^{-1}$ in Fig. B have a redshift and become weak; absorption peaks at $1167 \mathrm{~cm}^{-1}$ and $1031 \mathrm{~cm}^{-1}$ narrows down, which indicates $\left[\mathrm{HSO}_{4}\right]^{-}$in $\left[\mathrm{HSO}_{3} \text {-bmim }\right]^{+}\left[\mathrm{HSO}_{4}\right]^{-}$reacts with $\mathrm{ZrO}_{2}$ that causes the change of absorption peak of $\left[\mathrm{HSO}_{4}\right]^{-}$. One possibility is that $\left[\mathrm{HSO}_{4}\right]^{-}$combines with the alkali centre of $\mathrm{ZrO}_{2}$. Other absorption peaks don't change, indicates that the imidazole ring doesn't react with $\mathrm{ZrO}_{2}$.

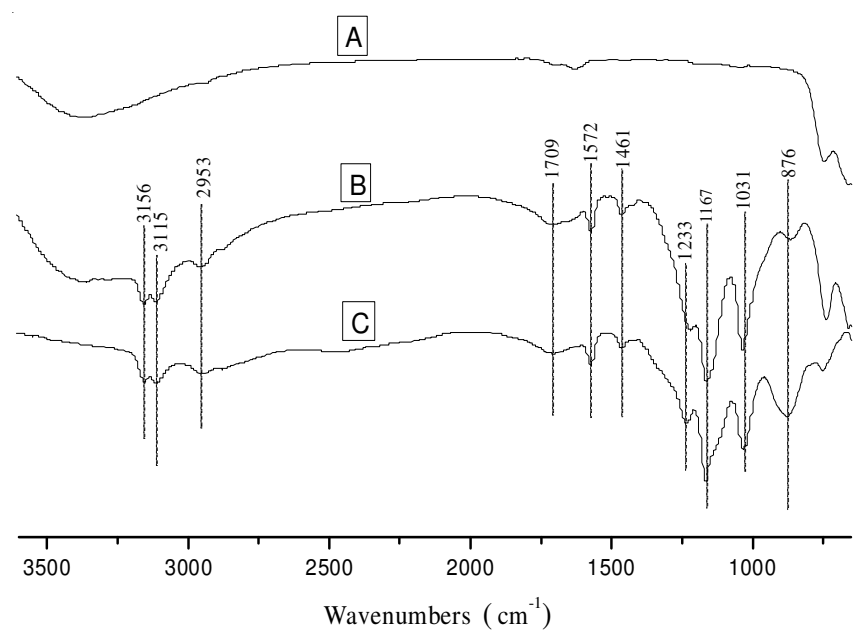

Fig. 2. FT-IR spectra of $\mathrm{ZrO}_{2}(\mathrm{~A}),\left[\mathrm{HSO}_{3}-\text { bmim }\right]^{+}\left[\mathrm{HSO}_{4}\right]^{-} / \mathrm{ZrO}_{2}(\mathrm{~B})$ and $\left[\mathrm{HSO}_{3}-\text { bmim }\right]^{+}\left[\mathrm{HSO}_{4}\right]^{-}(\mathrm{C})$ samples 
Thermostability of $\mathrm{ZrO}_{2}$ and $\left[\mathrm{HSO}_{3} \text {-bmim }\right]^{+}\left[\mathrm{HSO}_{4}\right]^{-/}$ $\mathrm{ZrO}_{2}$ : Fig. 3 are the TG curves of $\mathrm{ZrO}_{2}$ and $\left[\mathrm{HSO}_{3} \text {-bmim }\right]^{+}$ $\left[\mathrm{HSO}_{4}\right]^{-} / \mathrm{ZrO}_{2}$. It shows that $\mathrm{ZrO}_{2}$ losses weight smoothly in testing range which may be due to the thermal decomposition of some substances in prepared $\mathrm{ZrO}_{2}$ or the impurities adsorbed through the process of sample reserve. For $\left[\mathrm{HSO}_{3}-\right.$ bmim $]^{+}\left[\mathrm{HSO}_{4}\right]^{-} / \mathrm{ZrO}_{2}$, there is an obvious weight loss area between $300-550{ }^{\circ} \mathrm{C}$. The value of weight loss reaches maximum between $350-450{ }^{\circ} \mathrm{C}$ and the total value is about $20 \%$ weight, which indicates the load of ionic liquid $\left[\mathrm{HSO}_{3}-\mathrm{bmim}\right]^{+}\left[\mathrm{HSO}_{4}\right]^{-}$ on $\mathrm{ZrO}_{2}$ is $20 \%$ and catalyst $\left[\mathrm{HSO}_{3}-\mathrm{bmim}^{+}\left[\mathrm{HSO}_{4}\right]^{-} / \mathrm{ZrO}_{2}\right.$ can't be used when temperature is over $300{ }^{\circ} \mathrm{C}$.

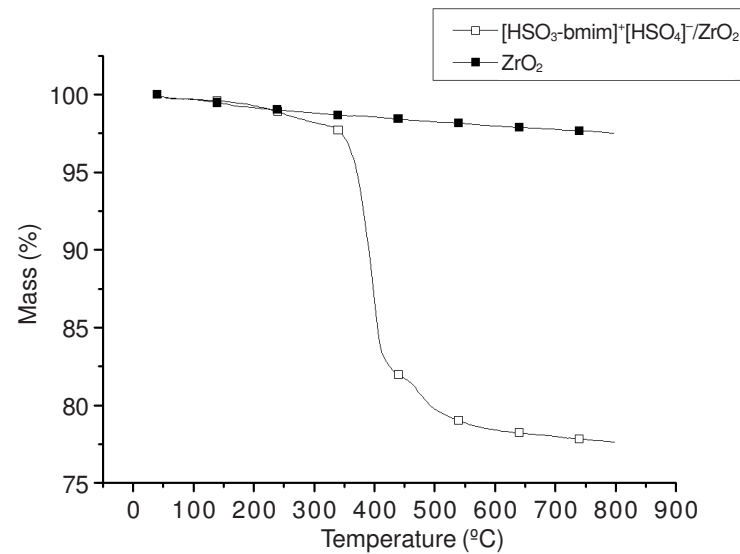

Fig. 3. TG analysis of $\mathrm{ZrO}_{2}$ and $\left[\mathrm{HSO}_{3} \text {-bmim }\right]^{+}\left[\mathrm{HSO}_{4}\right]^{-} / \mathrm{ZrO}_{2}$ samples

Surface appearance of $\mathrm{ZrO}_{2}$ and $\left[\mathrm{HSO}_{3}-\mathrm{bmim}\right]^{+}$ $\left[\mathrm{HSO}_{4}\right]^{-} / \mathrm{ZrO}_{2}$ : Fig. 4 are the SEM photos of $\mathrm{ZrO}_{2}$ and $\left[\mathrm{HSO}_{3}-\right.$ bmim $]^{+}\left[\mathrm{HSO}_{4}\right]^{-} / \mathrm{ZrO}_{2}$, in which (a) and (b) are SEM photos of $\mathrm{ZrO}_{2}$, the others are SEM photos of $\left[\mathrm{HSO}_{3}-\text { bmim }\right]^{+}\left[\mathrm{HSO}_{4}\right]^{-} /$ $\mathrm{ZrO}_{2}$. The contrast of (a), (b), (c) and (d) shows that after loading ionic liquid, the surface appearance of $\mathrm{ZrO}_{2}$ turns rough, which indicates ionic liquid is truly loaded on $\mathrm{ZrO}_{2}$. This not only increase the dispersity of ionic liquid, improve the catalytic activity, but also reduce the loss of ionic liquid and enhance the reutilization rate, which is good for the stability of the catalyst. In photos (c) and (d), there are obvious honeycomb multi-hole loosened structure, which is beneficial to improve the superficial area and the surface free energy of the catalyst and then improve its catalytic activity.

Loading rate of $\left[\mathrm{HSO}_{3}-\mathrm{bmim}\right]^{+}\left[\mathrm{HSO}_{4}\right]^{-} / \mathrm{ZrO}_{2}$ : The elementary analysis of $\left[\mathrm{HSO}_{3}-\mathrm{bmim}\right]^{+}\left[\mathrm{HSO}_{4}\right]^{-} / \mathrm{ZrO}_{2}$ shows that the quality scores of $\mathrm{C}, \mathrm{H}, \mathrm{N}$ are 7.37, 2.12 and $1.86 \%$, respectively. According to the analytical result of nitrogen content, the quality scores of $\left[\mathrm{HSO}_{3} \text {-bmim }\right]^{+}\left[\mathrm{HSO}_{4}\right]^{-}$in catalyst $\left[\mathrm{HSO}_{3}-\right.$ bmim $]^{+}\left[\mathrm{HSO}_{4}\right]^{-} / \mathrm{ZrO}_{2}$ can be calculated to be $21.01 \%$.

Catalytic property of $\left[\mathrm{HSO}_{3}-\mathrm{bmim}\right]^{+}\left[\mathrm{HSO}_{4}\right]^{-} / \mathrm{ZrO}_{2}$ in esterification reaction: The influences of different conditions for the esterification reaction between $0.05 \mathrm{M}$ maleic anhydride and $0.2 \mathrm{M}$ iso-octanol are listed in Table- 1 . The contrast of entry 1 and 2 shows that under the same conditions $\mathrm{ZrO}_{2}$ has certain catalysis to the esterification reaction, for it can improve the conversion rate of maleic anhydride. entry 3-5 show that ionic liquid $\left[\mathrm{HSO}_{3}-\mathrm{bmim}\right]^{+}\left[\mathrm{HSO}_{4}\right]^{-}$and $\left[\mathrm{HSO}_{3}{ }^{-}\right.$ bmim $]^{+}\left[\mathrm{HSO}_{4}\right]^{-} / \mathrm{ZrO}_{2}$ both have excellent catalysis to the reaction, while the auxoaction of which there is toluene is better than that of cyclohexane, which may be caused by the low boiling point of cyclohexane. Data from entry 6 to entry 9 show that the conversion rate of maleic anhydride continuously improve with the increase of $\left[\mathrm{HSO}_{3} \text {-bmim }\right]^{+}\left[\mathrm{HSO}_{4}\right]^{-} / \mathrm{ZrO}_{2}$, until the dosage of catalyst reach to $0.8 \mathrm{~g}$. As a result, the best addition amount of catalyst is $0.8 \mathrm{~g}$. Entry 10, 11, 12 and 13 shows the influence of different addition amount of toluene to the conversion rate of maleic anhydride. The result indicates that the best addition amount of toluene is $6 \mathrm{~g}$. Entry 14, 15, 16, 17 and 18 shows the conversion of maleic anhydride versus time, from which we can see the reaction reaches to balance in $100 \mathrm{~min}$, so that the best reaction time is $100 \mathrm{~min}$.
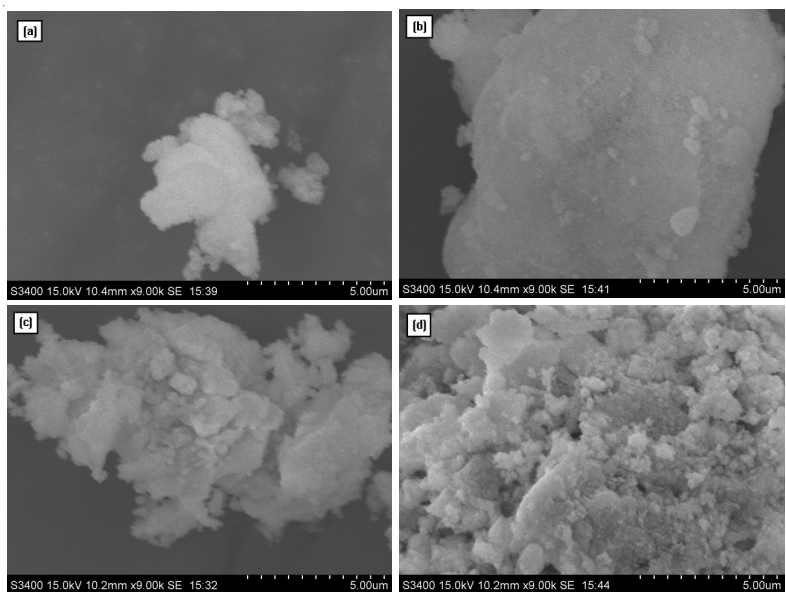

Fig. 4. SEM analysis of $\mathrm{ZrO}_{2}$ and $\left[\mathrm{HSO}_{3} \text {-bmim }\right]^{+}\left[\mathrm{HSO}_{4}\right]^{-} / \mathrm{ZrO}_{2}$ samples

Fig. 5 shows the reutilization property of $\left[\mathrm{HSO}_{3}-\right.$ bmim $]^{+}\left[\mathrm{HSO}_{4}\right]^{-}$and $\left[\mathrm{HSO}_{3}-\mathrm{bmim}\right]^{+}\left[\mathrm{HSO}_{4}\right]^{-} / \mathrm{ZrO}_{2}$. The result indicates that after being reused for 3 times, the catalytic property of $\left[\mathrm{HSO}_{3} \text {-bmim }\right]^{+}\left[\mathrm{HSO}_{4}\right]^{-}$starts to reduce obviously, which is probably caused by the loss of ionic liquid, while the catalytic property of $\left[\mathrm{HSO}_{3}-\text { bmim }\right]^{+}\left[\mathrm{HSO}_{4}\right]^{-} / \mathrm{ZrO}_{2}$ doesn't reduce obviously after being reused for 9 times and the conversion rate of maleic anhydride is still up to $94.9 \%$. The result shows that the load of $\left[\mathrm{HSO}_{3} \text {-bmim }\right]^{+}\left[\mathrm{HSO}_{4}\right]^{-}$on $\mathrm{ZrO}_{2}$ is firm and the catalyst can be reused without any activation treatment, also there are no catalyst poisoning problems.

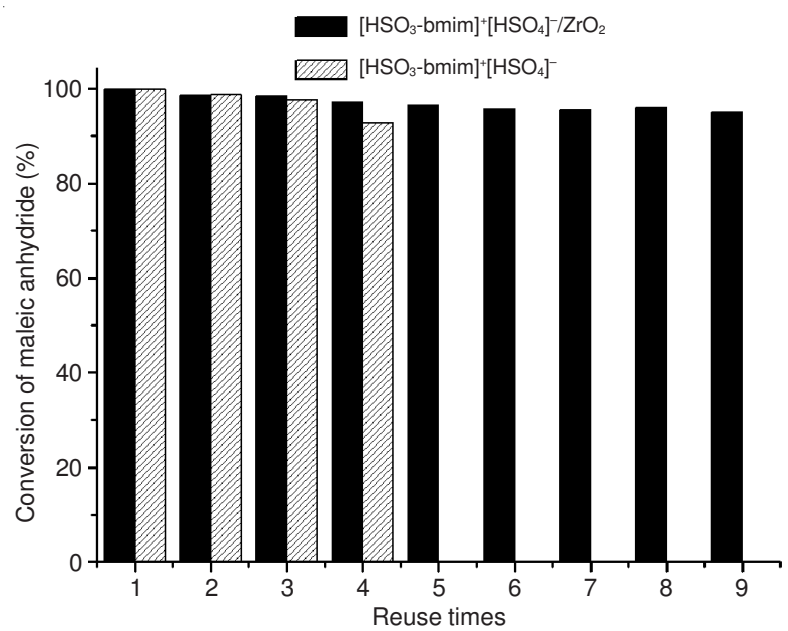

Fig. 5. Catalytic performance of catalyst reused of $\left[\mathrm{HSO}_{3}-\text { bmim }\right]^{+}\left[\mathrm{HSO}_{4}\right]^{-}$ and $\left[\mathrm{HSO}_{3} \text {-bmim }\right]^{+}\left[\mathrm{HSO}_{4}\right]^{-} / \mathrm{ZrO}_{2}$ samples 
TABLE-1

EFFECT OF DIFFERENT FACTORS ON ESTERIFICATION OF MALEIC ANHYDRIDE AND ISOOCTANOL

\begin{tabular}{|c|c|c|c|c|c|c|c|}
\hline Entry & Catalyst & $\begin{array}{c}\text { Catalyst } \\
\text { dosage }(\mathrm{g})\end{array}$ & $\begin{array}{l}\text { Reaction } \\
\text { temp. }\left({ }^{\circ} \mathrm{C}\right)\end{array}$ & $\begin{array}{c}\text { Reaction } \\
\text { time }(\min )\end{array}$ & $\begin{array}{c}\text { Water- } \\
\text { carrying agent }\end{array}$ & $\begin{array}{l}\text { Water-carrying } \\
\text { agent dosage/g }\end{array}$ & $\begin{array}{c}\text { Conversion of maleic } \\
\text { anhydride } / \%\end{array}$ \\
\hline 1 & - & - & 140 & 100 & Toluene & 6 & 70.3 \\
\hline 2 & $\mathrm{ZrO}_{2}$ & 0.8 & 140 & 100 & Toluene & 6 & 86.4 \\
\hline 3 & {$\left[\mathrm{HSO}_{3}-\mathrm{bmim}\right]^{+}\left[\mathrm{HSO}_{4}\right]^{-}$} & 0.2 & 130 & 75 & Cyclohexane & 6 & 99.2 \\
\hline 4 & {$\left[\mathrm{HSO}_{3}-\mathrm{bmim}\right]^{+}\left[\mathrm{HSO}_{4}\right]^{-}$} & 0.2 & 140 & 75 & Toluene & 6 & 99.8 \\
\hline 5 & {$\left[\mathrm{HSO}_{3}-\mathrm{bmim}^{+}\left[\mathrm{HSO}_{4}\right]^{-} / \mathrm{ZrO}_{2}\right.$} & 0.8 & 130 & 100 & Cyclohexane & 6 & 99.4 \\
\hline 6 & {$\left[\mathrm{HSO}_{3}-\mathrm{bmim}^{+}\left[\mathrm{HSO}_{4}\right]^{-} / \mathrm{ZrO}_{2}\right.$} & 0.4 & 140 & 100 & Toluene & 6 & 90.5 \\
\hline 7 & {$\left[\mathrm{HSO}_{3}-\mathrm{bmim}\right]^{+}\left[\mathrm{HSO}_{4}\right]^{-} / \mathrm{ZrO}_{2}$} & 0.6 & 140 & 100 & Toluene & 6 & 93.4 \\
\hline 8 & {$\left[\mathrm{HSO}_{3}-\mathrm{bmim}^{+}\left[\mathrm{HSO}_{4}\right]^{-} / \mathrm{ZrO}_{2}\right.$} & 0.8 & 140 & 100 & Toluene & 6 & 99.8 \\
\hline 9 & {$\left[\mathrm{HSO}_{3}-\mathrm{bmim}^{+}\left[\mathrm{HSO}_{4}\right]^{-} / \mathrm{ZrO}_{2}\right.$} & 1.0 & 140 & 100 & Toluene & 6 & 99.8 \\
\hline 10 & {$\left[\mathrm{HSO}_{3}-\mathrm{bmim}^{+}\left[\mathrm{HSO}_{4}\right]^{-} / \mathrm{ZrO}_{2}\right.$} & 0.8 & 140 & 100 & Toluene & 4 & 97.6 \\
\hline 11 & {$\left[\mathrm{HSO}_{3}-\mathrm{bmim}^{+}\left[\mathrm{HSO}_{4}\right]^{-} / \mathrm{ZrO}_{2}\right.$} & 0.8 & 140 & 100 & Toluene & 5 & 98.3 \\
\hline 12 & {$\left[\mathrm{HSO}_{3}-\mathrm{bmim}^{+}\left[\mathrm{HSO}_{4}\right]^{-} / \mathrm{ZrO}_{2}\right.$} & 0.8 & 140 & 100 & Toluene & 6 & 99.8 \\
\hline 13 & {$\left[\mathrm{HSO}_{3}-\mathrm{bmim}\right]^{+}\left[\mathrm{HSO}_{4}\right]^{-} / \mathrm{ZrO}_{2}$} & 0.8 & 140 & 100 & Toluene & 8 & 96.2 \\
\hline 14 & {$\left[\mathrm{HSO}_{3}-\mathrm{bmim}\right]^{+}\left[\mathrm{HSO}_{4}\right]^{-} / \mathrm{ZrO}_{2}$} & 0.8 & 140 & 25 & Toluene & 6 & 81.4 \\
\hline 16 & {$\left[\mathrm{HSO}_{3}-\mathrm{bmim}\right]^{+}\left[\mathrm{HSO}_{4}\right]^{-} / \mathrm{ZrO}_{2}$} & 0.8 & 140 & 75 & Toluene & 6 & 98.5 \\
\hline 17 & {$\left[\mathrm{HSO}_{3}-\mathrm{bmim}^{+}\left[\mathrm{HSO}_{4}\right]^{-} / \mathrm{ZrO}_{2}\right.$} & 0.8 & 140 & 100 & Toluene & 6 & 99.8 \\
\hline 18 & {$\left[\mathrm{HSO}_{3}-\mathrm{bmim}^{+}\left[\mathrm{HSO}_{4}\right]^{-} / \mathrm{ZrO}_{2}\right.$} & 0.8 & 140 & 125 & Toluene & 6 & 99.8 \\
\hline
\end{tabular}

\section{Conclusion}

An ionic liquid $\left[\mathrm{HSO}_{3}-\text { bmim }\right]^{+}\left[\mathrm{HSO}_{4}\right]^{-}$is loaded on $\mathrm{ZrO}_{2}$ through immersion method to prepare a novel catalyst $\left[\mathrm{HSO}_{3}-\right.$ bmim $]^{+}\left[\mathrm{HSO}_{4}\right]^{-} / \mathrm{ZrO}_{2}$ with good thermal stability and reutilization property. Under the following reaction conditions: $140{ }^{\circ} \mathrm{C}, 0.05 \mathrm{~mol}$ maleic anhydride, $0.2 \mathrm{~mol}$ iso-octanol and $0.8 \mathrm{~g}$ catalyst, after reacting for $100 \mathrm{~min}$, the conversion rate of maleic anhydride can reach to $99.8 \%$ without any treating and the conversion rate of maleic anhydride is still up to $94.9 \%$ after catalyst being reused for 9 times, which is much more than ionic liquid $\left[\mathrm{HSO}_{3} \text {-bmim }\right]^{+}\left[\mathrm{HSO}_{4}\right]^{-}$.

\section{ACKNOWLEDGEMENTS}

This work was supported by the Chinese Academy of Forestry and the Key Technology R\&D Program of China (2012BAD32B03).

\section{REFERENCES}

1. D.C. Forbes and K.J. Weaver, J. Mol. Catal. A, 214, 129 (2004).

2. Y.Q. Deng, Ionic Liquid-Property, Preparation and Application, Beijing: China Petrochemical Press, p. 285 (2006).
3. N. Clousier, R. Moucel, P. Naik, P.J. Madec, A.C. Gaumont and I. Dez, Comptes Rendus Chimie, 14, 680 (2011).

4. C.P. Mehnert, R.A. Cook, N.C. Dispenziere and M. Afework, J. Am. Chem. Soc., 124, 12932 (2002).

5. Z.J. Xu, H. Wan and G.F. Guan, Petrochem. Technol., 39, 971 (2010).

6. B. Zou, Y. Hu, D.H. Yu, L. Jiang, W.M. Liu and P. Song, Colloid Surf. B, 88, 93 (2011)

7. Y.L. Gu, A. Karam, F. Jérôme and J. Barrault, Org. Lett., 9, 3145 (2007).

8. J.Y. Ren, S.J. Wang, W.G. Cheng, et al., CIESC J., 60, 1471 (2009).

9. Q. Lin, H.Y. Fu, M.L. Yuan, H. Chen and X.J. Li, Acta Pysico-Chimica Sinica, 22, 1272 (2006).

10. K. Qiao, R. Sugimura, Q. X. Bao, D. Tomida and C. Yokoyamal, Catal. Commun., 9, 2470 (2008).

11. R.S. Babu, P. Prabhu and S.S. Narayanan, Colloid Surf. B, 88, 755 (2011).

12. J.S. Zhang, H. Wan and G.F. Guan, Chem. Reaction Eng. Technol., 24, 503 (2008).

13. J.C. Shen, J.P. Guo, Y.M. Sun, B.Y. Tang, X.H. Chen and D.L. Yin, Chinese J. Catal., 31, 827 (2010).

14. A.C. Cole, J.L. Jensen and L. Ntai, J. Am. Chem. Soc., 124, 5962 (2002).

15. J. Chen, Investigation of Preparing Liquid Fuels from Fats by Catalytic Cracking[D]. Beijing: Chinese Academy of Forestry, p. 42 (2010).

16. F.J. Li, Study of Esterification Catalyzed by Brønsted Acid Ionic Liquids, Hangzhou: Zhejiang University, p. 34 (2008). 